\title{
Multivariate Effects of Level of Education, Computer Ownership, and Computer Use on Female Students' Attitudes towards CALL
}

\author{
Mehrak Rahimi (Corresponding author) \\ English Department, Faculty of Humanities \\ Shahid Rajaee Teacher Training University, Lavizan, Tehran, Iran \\ E-mail: mehrakrahimi@yahoo.com \\ Samaneh Yadollahi \\ English Department, Faculty of Humanities \\ Shahid Rajaee Teacher Training University, Lavizan, Tehran, Iran \\ E-mail: yadollahi88@yahoo.com
}

Received: January 5, 2012

Accepted: January 26, 2012

Published: April 1, 2012

doi:10.5539/elt.v5n4p108

URL: http://dx.doi.org/10.5539/elt.v5n4p108

\begin{abstract}
The aim of this study was investigating Iranian female students' attitude towards CALL and its relationship with their level of education, computer ownership, and frequency of use. One hundred and forty-two female students (50 junior high-school students, 49 high-school students and 43 university students) participated in this study. They filled in A-CALL questionnaire that assessed their attitudes towards CALL with respect to four factors: effectiveness of CALL vs. non-CALL, surplus value of CALL, teacher influence, and degree of exhibition to CALL. The findings revealed that the sample had a general positive attitude towards CALL while they showed the highest positive attitudes towards teacher influence and the lowest positive attitudes towards effectiveness of CALL vs. non-CALL. Students' attitude toward CALL across level of education was found to be significantly different just in degree of exhibition to CALL; while university students had the highest level of positive attitudes in this regard. Further, computer ownership could make a difference in students' attitude towards teacher influence. No statistically significant difference was found between the attitudes of those students who used computer more frequently and those students who did not use it quite often.
\end{abstract}

Keywords: CALL, Students, Attitude, Computer use, Computer ownership, Female

\section{Introduction}

The impact of globalization and the rapid growth of information and communication technologies (ICTs) have resulted in providing more opportunities for language educators to integrate computers into language teaching/learning process. Computer assisted language learning (CALL) has experienced a continuous progression over the past three decades. Culhane (2003) believes that the question of whether it is possible to use computer for teaching language during the 1980s changed to the inquiry of why to implement computers in this field in the 1990s, and now the general issue in this regard is how to integrate computers in language education. Research shows that the issue of how to use computers in language instruction is highly related to language learners' individual variables. Among these personal factors computer attitudes are a major factor that affect human computer interaction. There is evidence in the literature that individuals' positive attitudes towards computer-based instruction influence their willingness to sustain using computers for learning (Liaw, Huang, \& Chen, 2007). In spite of a wide and rapidly expanding literature on computer attitude and its relationship with personal variables such as age and gender (Meelissen, \& Drent, 2008) and context of learning (Bovée, Voogt, \& Meelissen, 2007) only a few studies focused on CALL attitude (Vandewaeterea, \& Desmet, 2009) and even smaller number of research have dealt with CALL attitude of students in pre-university education.

Taking these issues into account, the present study aims to investigate Iranian students' attitude towards using computer to learn English. Apart from that, the possible relationship between their attitude and computer accessibility and frequency of use and level of education is investigated. Therefore, the study aims at finding answers to the following research questions: 


\section{What is Iranian students CALL attitude?}

2. Is Iranian students' CALL attitude related to their computer ownership, computer use, and level of education?

\subsection{CALL Development}

Computers have been used for language teaching/learning since 1960s. Warschauer \& Healey (1998) divided the development of CALL into three phases: behaviorist CALL, communicative CALL, and integrative CALL. The first phase, behaviorist CALL, was recognized from the late 1950s and then implemented through the 1960s and 1970s when the audio-lingual method was widely used. This provided students with the repetitive drills and practice, grammatical explanation and translation. In this phase, the computer was used as a tutor, presenting drill exercises without interactive feedback.

The second phase or communicative CALL, based on cognitive theories that identified learning as a creative process, began in the late 1970s and continued through the 1980s. This phase of CALL offered more focus on the use of language rather than the language itself. In this phase, the skill practice was provided in a non-drill format like language games, reading, and text reconstruction. While the computer was still used as a tutor, it gave students choice, control, and interaction. Furthermore, during this phase the computer was also used as the stimulus (e.g. to stimulate writing, discussions) or as a tool, i.e., it did not offer instructional materials, but was used for creating or understanding the language through programs such as word processors, spelling and grammar checkers (Moras, 2001).

The third phase, namely the integrative CALL, is currently predominant. It is based on multimedia technology and the Internet where text, graphics, sound, animation and video are combined. Also, the integrative CALL has looked at the language learning from the perspective of socio-cognitive theory which attaches a great importance to authentic use of language in meaningful contexts. It also gives emphasis to the integration of each skill by means of multimedia networked computers providing foreign language learners with opportunities to use information communication technology (Akbulut, 2008). Moreover, integrative CALL is considered as the integrated nature of technology as a tool rather than as an isolated technique (Opp-Beckman, 2002). This new approach incorporates many aspects of constructivism.

\subsection{CALL Attitude}

One of the important factors affecting computer use, especially in learning and teaching, is the attitude towards computers. Despite the great importance of this construct, no particular definition of computer-related attitude is available (Liaw, 2002). One of the most common definitions of attitude is derived from a well-studied area in the field of social psychology, Fishbein and Ajzen's Reasoned Action Theory. Fishbein and Ajzen (1975) defined attitude as: "a learned predisposition to respond in a consistently favorable or unfavorable manner with respect to a given object" (p. 6). According to this theory, individuals' attitudes determine their behavioral intensions and in turn result in actual behaviors. In the context of computer use in language learning it can be deduced that a student's level of computer attitude determines the degree he/she intends to use computer in learning language. Research on computer attitudes showed that this construct consists of three components: cognitive, affective, and behavioral (Liaw, 2002). However, more detailed analysis of CALL attitude revealed that the construct could be decomposed into four components (Vandewaeterea, \& Desmet, 2009): effectiveness of CALL vs. non-CALL, surplus value of CALL, teacher influence, and degree of exhibition to CALL.

Research has proven that there is a relationship between computer use and positive CALL attitude. Levine and Donitsa-Schmidt (1998), for instance, found that an individual's behavioral intentions are determined by his/her attitudes towards computer. Similarly, Loyd \& Gressard (1984) found that a student's attitude towards CALL is a good indicator of his/her usage of computer technology. Ayres (2002) reported a definite correlation between students' high motivation and the perceived need of CALL. In another study carried out by Mitra (1997), learners' attitudes towards computers and their CALL attitudes were found to be related. Allum's (2002) study proved that university students had positive feelings about CALL and suggested that CALL should be mixed with teaching regular classes. Debski's (2000) findings also supported a positive attitude among university students towards CALL and added that they preferred CALL to traditional classes.

In line with this, it has been documented in the literature that CALL attitude can be related to students' achievement in language (Lacina, 2004; Warschauer, Knoebel, \& Stone, 2004). Chapelle and Jamieson (1986) studied the use of CALL lessons in the acquisition of English as a second language and reported that students who worked harder at learning English spent a lot of time using CALL and had a more positive attitude toward it. They also reported a significant relationship between language learners' motivation and computer use and attitude.

Tsou, Wang, \& Li (2002) suggested that a well-designed CALL can efficiently help students to acquire knowledge and skills at their own paces. In this regard, they believe that "with the help of multimedia and interactive techniques, 
CALL can simulate real life circumstance in order to aid students to develop practical knowledge and control their own learning" (p. 417). As a result of that, students find using technology tools (e.g. the Internet) as an interesting and useful tool in their English classes (Young, 2003), while it is equally effective as face-to-face instruction (Osman, \& Ahmed, 2003). Moreover, students who used to be shy in face-to-face discussion and who were considered low achievers in language learning were found to become more active participants in computer-assisted classroom discussion (Kelm, 1992). Consequently, the use of ICT tools in EFL classes could motivate student learning and provide students with a less stressful environment to express their opinions freely (Young, 2003) and as a result of that a positive attitude may take shape with regard to learning languages with CALL.

\subsection{Computer Access, Use, and Attitude}

Computer use which is characterized as the total number of hours a week or day individuals spend working with computer has been found to be one of the most important factors that influence computer attitude (Beckers, \& Schmidt, 2003; Bozionelos, 2001). There is evidence in the literature that computer experience leads to a positive attitude toward technology and decreases the level of computer anxiety (Matthews, \& Shrum, 2003). Being in the environment with computer and benefiting from its applications reduce negative attitudes toward technology and lessen fear of using computer (Baloglu, \& Cevik, 2008). It has been suggested that computer attitudes are related to computer experience and formal training with computers by prior attendance at a computer course has a positive effect on users' confidence (Mcilroy, Sadler, \& Boojawon, 2007).

Owning a computer at home or regular computer access at work is highly related to the frequency of computer use which can decrease negative attitudes towards computer (Brosnan, 1999; Baloglu, \& Cevik, 2008). It is suggested that uneven distribution of access and use can create differences in computer literacy of students (Kuhlemeier, \& Hemker, 2007) which may result in negative computer attitudes. If students have access to computers at home, they use computers more frequently and this extended experience with technology will contribute to positive attitudes (Selwyn, 1998).

\section{Methodology}

\subsection{Participants}

One hundred and forty-two female students took part in this study. Of the sample, 50 were junior high-school students (35.2\%), 49 were high- school students $(34.5 \%)$ and 43 were university students $(30.3 \%)$. The participants ranged in age from 12 to 39 (mean=17.77; $\mathrm{SD}=4.51$ ). Fifty-six percent of the sample reported to own a personal computer. Half of the sample reported to have access to computers at the educational centers where they studied.

\subsection{Research Instrument}

In order to collect the data for this study, a questionnaire was used. The questionnaire consisted of two parts: the first part of the questionnaire included the participants' demographic information such as age, access to the computer at home and at educational center (school or university), and the amount of their computer use. The second part was the Attitude towards Computer-Assisted Language Learning (A-CALL) questionnaire validated by Vandewaetere and Desmet (2009). A-CALL is a 20-item questionnaire which examines EFL learners' attitude towards CALL. Each item is rated on a seven-point Likert scale ranging from 1 (totally disagree), over 4 (neutral) to 7 (totally agree). All items except items 2-5 and items 19-20 have been written in a positive direction.

A-CALL consists of four subsets of items: Factor 1 (effectiveness of CALL vs. non-CALL) has four items (2-5), factor 2 (surplus value of CALL) has 10 items $(1,6-12,16-17)$, factor 3 (teacher influence) has three items (13-15), and factor 4 (degree of exhibition to CALL) consists of three items (18-20).

To estimate A-CALL's reliability, Vandewaetere and Desmet (2009) have used internal consistency technique and Cronbach's Alpha of four subscales reported to be: $0.74,0.80,0.86$, and 0.91 respectively. In order to establish construct validity of the instrument, they used an exploratory factor analysis to determine the number of factors underlying the 20 questions. This technique resulted in four factors which explained $54.25 \%$ of the total variance.

To be able to use A-CALL in this study, it was first translated into Persian, and then back-translated to ensure the accuracy of translation. Then the translated version was proofread by language experts and required changes were done. The reliability of Persian version was calculated through internal consistency technique and the Cronbach's Alpha was found to be 0.75 .

\subsection{Procedure}

The questionnaire was administered to 150 Iranian students in three levels of education including junior high-school, high-school, and higher education (50 students from each level of education). One hundred and forty-two 
questionnaires were completed by respondents and were returned. Responses were coded and analyzed through the use of SPSS 17.

\section{Results}

\subsection{Descriptive Statistics}

Table 1 summarized 142 university students' means and standard deviations on A-CALL and its subsections. As table 1 illustrates, the participants had a general positive attitude towards CALL $(\mathrm{M}=4.74)$. They had the highest positive attitudes (mean=5.30) towards factor 3 (teacher influence) and the lowest positive attitudes (mean=4.12) towards factor 1 (effectiveness of CALL vs. non-CALL).

\subsection{Multivariate Analyses Of Variance (MANOVA)}

A 3-way between-groups multivariate analysis of variance (MANOVA) was conducted in which four factors of CALL attitudes served as the dependent variables and students' level of education (3 levels: junior high-school, high-school, and university), computer ownership (two levels), and computer use hours (five levels: never, 1 hour, 2 hours, 3 hours, 4 hours, and more than 4 hours) were the independent variables. Preliminary assumption testing was conducted to check for normality, linearity, and univariate and multivariate outliers. Homogeneity of variance-covariance matrices was assessed by Box's M Test of Equality of Covariance Matrices (Box's M=142.05; $\mathrm{F}=1.102 ; p=.231>.001)$ implying that the observed covariance matrices of the dependent variables were equal across groups. Levene's test of Equality of Error Variances showed that the assumption of equality of variance for dependent variables was not violated.

The results from the Multivariate tests table for the first main effect suggested that there was a statistically significant difference between participants with different levels of education on the combined dependent variables (Wilks' Lambda $=.853 ; \mathrm{F}=2.506 ; p=.000<.001$; partial eta squared=.077). When the results for the dependent variables were considered separately, the only difference to reach the statistical significance was factor four that is the degree of exhibition to CALL (table 2).

An inspection of the mean scores (table 3) indicated that university students' attitude towards the degree of exhibition to CALL was higher than that of junior high-school and high-school students. Their mean score in factor one (effectiveness of CALL vs. non CALL) was also higher than school students' means. More interestingly, junior high-school students were found to have the highest positive attitudes in factors 2 (surplus value of CALL) and 3 (teacher influence) when they were compared with high-school and university students.

Investigating the second main effect showed that there was not a statistically significant difference between the attitudes of those students who had computers and the attitudes of those who did not have computers at home on the combined dependent variables. (Wilks' Lambda $=.955 ; \mathrm{F}=1.44 ; p=.225>.001$; partial eta squared $=.045$ ). When the results for the dependent variables were considered separately, the only difference to reach the statistical significance was factor 3 (teacher influence) (table 4).

An inspection of the mean scores (table 5) indicated that those who did not have a computer at home had higher positive attitude towards the degree of exhibition to CALL in comparison to those who owned a computer. However, the attitudes of those who owned a computer were marginally higher than the attitudes of those who did not have a computer at home in other three factors.

Investigating the third main effect showed that there was not a statistically significant difference between the attitudes of those students who used computer more frequently and the attitudes of students who did not use it quite often (Wilks' Lambda $=.895 ; \mathrm{F}=.858 ; p=.619>.001$; partial eta squared=.027). When the results for the dependent variables were considered separately, no difference reached the statistical significance.

Further, 3-way and 2-way interactions were investigated. Analyses did not detect a significant 3-way level of education by ownership by the frequency of computer use interaction effect (Wilks' Lambda = .959; $\mathrm{F}=1.29$; $p=.279>.001$; partial eta squared $=.041$ ). Similarly, there was not any significant 2 -way interaction of ownership by the frequency of computer use (Wilks' Lambda $=.958 ; \mathrm{F}=.470 ; p=.758>.001$; partial eta squared=.015), level of education by the frequency of computer use (Wilks' Lambda $=.764 ; \mathrm{F}=1.414 ; p=.094>.001$; partial squared $=.065$ ), and level of education by ownership (Wilks' Lambda $=.933 ; \mathrm{F}=2.18 ; p=.075>.001$; partial squared $=.067$ ).

\section{Discussion}

The findings of the present study revealed that Iranian students' CALL attitude was positive in general which is in full agreement with previous studies such as Fančovičová and Prokop (2008), Kilic (2001), and Sanders and Morrison-Shetlar (2001). This finding supports the fact that the ubiquity of technology in the $21^{\text {st }}$ century resulted in positive perceptions towards using computers in teaching and learning of any subject in general and foreign languages 
in particular. In this regard, Ayres (2002) found that students perceive CALL in relation to their needs and they "appreciate and value the learning that they do using the computers" (p. 247). Similarly, Greenfield (2003) found that $84 \%$ of the students who participated in her study indicated a preference for learning English with computers in their interview responses.

The detailed analysis indicated that students had a highly positive attitude towards CALL in terms of teacher influence while they showed a negative attitude towards the effectiveness of CALL vs. non-CALL. Firstly, the reason may lie in the fact that a larger number of participants were school students and it is believed that students in this level of education are more likely to consider their teachers as the role models whose attitudes are implicitly transferred to their students (Kalanda, 2005). In this sense, teachers' proficiency in computer use and their enthusiasm and positive attitudes to CALL greatly affect students' perception of CALL in language learning (Vandewaetere \& Desmet, 2009). Secondly, students' negative attitude to the effectiveness of CALL vs. non-CALL classes among the participants can be related to the fact that the comparative use of computers is very rare in language classes in Iran. That is, most language classes in Iran are taught based on traditional methods without using computers. Therefore, comparing and perceiving the effectiveness of CALL vs. non-CALL classes may be difficult for students.

Moreover, the finding indicated that students in different levels of education hold different degrees of positive attitudes towards using computers in language learning. Particularly, it was found that both the degree of exhibition and effectiveness of CALL vs. non CALL were higher among university students in comparison to junior high-school and high-school students. It may account that university students are not only more computer literate and have less computer anxiety (Fančovičová \& Prokop, 2008), but also they perceive the value of using computers in their academic tasks, since they are more exposed to technology and have more opportunities to use computers for course-related activities (Hong, Ridzuan, \& Kuek, 2003). As the previous studies indicate, digital gender divide is closing and today's female students are becoming more experienced in computer use (Lin \& Yu, 2008) and thus they take advantage of the technology according to their needs and preferences (Poynton, 2005) as they become more educated. It is even reported that female academics perceived themselves to be better in certain computer applications than males (Wong et al, 2005).

The findings also revealed that there is a high positive attitude towards CALL among junior high-school students in terms of surplus value of CALL and teacher influence. This positive attitude suggests that students identify computers as valuable and flexible tools helping them to learn language. It also indicates that nowadays, students are gaining more knowledge and computer experience through the increasingly widespread exposure to computers at school and at home (Liaw et al., 2007).

Moreover, no statistically significant difference between general attitudes of students who owned computers at home and those who did not have computers was found. However, particularly, teacher influence was the only factor in which there was a statistically significant difference. This implies the great influence of teachers on the formation of students' attitudes (Fontana, 1988; Moore, 1993) because teacher's positive attitude towards learning might have a positive impact on students' attitude toward language learning in general and language learning via computers in particular (Kalanda, 2005).

Interestingly, it was found that students who did not own computers at home hold more positive attitude toward CALL in the case of the degree of exhibition to CALL in comparison to those who owned a computer. It may imply that students with no computer at home value the stress-free atmosphere of CALL vs. face-to face and traditional language learning. However, in other three factors the attitudes of those who owned a computer were marginally higher than the attitudes of those who did not have a computer at home. This is in agreement with the findings of other studies which indicated that accessibility to computer promotes positive attitudes to computer use and they are interrelated (Bovée, Voogt, \& Meelissen, 2007; Baloglu, \& Cevik, 2008).

Additionally, this study revealed that there was not a statistically significant difference between the attitudes of those students who used computer more frequently and those students who did not use it quite often. This shows that widespread presence of technology in this era has made students familiar with computers and thus they have positive thoughts about computers. According to Akbulut (2008) foreign language learners reveal positive attitudes towards CALL due to the potential of computers to sustain autonomous learning, creativity, achievement, and instrumental benefits and their attitudes are not strongly affected by factors such as ownership or frequency of use (Fančovičová \& Prokop, 2008).

\section{Conclusion}

Students' positive attitude towards CALL shows that Iranian students are ready to embrace computer-based instruction. Based on the results of this study and the support gained from the literature, it can be claimed that most of the experience with CALL is idiosyncratic, and it is highly dependent on so many contextual and even personal factors. 
The following implications can help teachers and policy makers in this regard:

1. Before introducing CALL into the classroom, learners should be provided with the necessary skills required to use the computers properly and comfortably. This ensures that learners will be freed from computer anxiety and negative attitudes towards computers.

2. CALL should be integrated into the traditional classrooms as well. Actually in such classes the instructor is available for more assistance and answering the questions so that students are not deprived of human interaction.

In sum, being one of a few studies done regarding to CALL attitude in the Asian context in general, and in Iran in particular, this study revealed that there is an obvious need for further research on students' attitude towards using computers in language courses across the region.

\section{References}

Akbulut, Y. (2008). Exploration of the attitude of freshman foreign language students' toward using computers at a Turkish state university. The Turkish Online Journal of Educational Technology, 7. [Online] Available: http://www.eric.ed.gov/PDFS/ED499579.pdf

Allum, P. (2002). CALL and the classroom: The case for comparative research. ReCALL, 14, 146-166. http://dx.doi.org/10.1017/S0958344002001210

Ayres, R. (2002). Learner attitudes towards the use of CALL. Computer Assisted Language Learning, 15, 241-249. http://dx.doi.org/10.1076/call.15.3.241.8189

Baloglu, M., \& Cevik, V. (2008). Multivariate effects of gender, ownership, and the frequency of use on computer anxiety among high school students. Computers in Human Behavior, 24, 2639-2648. http://dx.doi.org/10.1016/j.chb.2008.03.003

Beckers, D., \& Schmidt, H. (2003). Computer experience and computer anxiety. Computers in Human Behavior, 19, 785-797. http://dx.doi.org/10.1016/S0747-5632(03)00005-0.

Bovée, C., Voogt, J., \& Meelissen, M. (2007). Computer attitudes of primary and secondary students in South Africa. Computers in Human Behavior, 23, 1762-1776. http://dx.doi.org/10.1016/j.chb.2005.10.004

Brosnan, M. J. (1999). Modeling technophobia: A case for word processing. Computers in Human Behavior, 15, 105-121. http://dx.doi.org/10.1016/S0747-5632(98)00020-X

Bozionelos, N. (2001). Computer anxiety: Relationship with computer experience and prevalence. Computers in Human Behavior, 17, 213-214. http://dx.doi.org/10.1016/S0747-5632(00)00039-X

Chapelle, C., \& Jamieson, J. (1986). Computer-Assisted Language Learning as a predictor of success in acquiring English as a second language. TESOL Quarterly, 20, 27-41. http://dx.doi.org/10.2307/3586387

Culhane, S. F. (2003). The electronic textbook for content-based second language learning. Paper presented at LET 2003 National Conference, Kansai Gaidai University, Japan.

Debski, R. (2000). Exploring the re-creation of a CALL innovation. Computer Assisted Language Learning, 13, 307-332. http://dx.doi.org/10.1076/0958-8221(200012)13:4-5;1-E;FT307

Fančovičová, J., \& Prokop, P. (2008). Students' attitude toward computer use in Slovaki. Eurasia Journal of $\begin{array}{lllll}\text { Mathematics, } \quad \text { Science } \quad \& \quad \text { Technology } & \text { Education, } & 4, & \text { 255-262. }\end{array}$ $\mathrm{http} / / /$ www.ejmste.com/v4n3/EURASIA_v4n3_Fancovicova.pdf

Fishbein, M., \& Ajzen, I. (1975). Belief, attitude, intention and behavior: An introduction to theory and research. California: Addison-Wesley Publishing Company.

Fontana, D. (1988). Psychology for teachers. England: The British Psychological Society, UK.

Greenfield, R. (2003). Collaborative e-mail exchange for teaching secondary ESL: A case study in Hong Kong. Language Learning \& Technology, 7, 46-70. http://lt.msu.edu/vol7num1/greenfield/default.html

Hong, K., Ridzuan, A. A., \& Kuek, M. (2003). Students' attitudes toward the use of the Internet for learning: A study at a university in Malaysia. Educational Technology \& Society, 6, 45-49. http://www.ifets.info/journals/6_2/5.html

Kelm, O. R. (1992). The use of synchronous computer networks in second language instruction: A preliminary report. Foreign Language Annals, 25, 441-545. http://dx.doi.org/j.1944-9720.1992.tb01127.x

Kilic, G. B. (2001). Descriptive study of students' attitudes toward computers and attitudes toward communicating on computers in an elementary science methods course. Turkish Online Journal of Distance Education, 2, 62-73. [Online] Available: https://tojde.anadolu.edu.tr/tojde3/pdf/5.pdf 
Kuhlemeier, H., \& Hemker, B. (2007). The impact of computer use at home on students' Internet skills. Computers and Education, 49, 460-480. http://dx.doi.org/10.1016/j.compedu.2005.10.004

Lacina, J. (2004). Promoting language acquisitions: Technology and English language learners. Childhood Education, 81, 113-115. http://www.questia.com/googleScholar.qst?docId=5008225574

Levine, T., \& Donitsa-Schmidt, S. (1998). Computer use, confidence, attitudes, and knowledge: A causal analysis. Computers in Human Behavior, 14, 125-146. http://dx.doi.org/10.1016/S0747-5632(97)00036-8

Liaw, S. S. (2002). An Internet survey for perceptions of computer and world wide web: Relationship, prediction, and difference. Computers in Human Behavior, 18, 17-35. http://dx.doi.org/10.1016/S0747-5632(01)00032-2

Liaw, S. S., Huang, H. M., \& Chen, G. D. (2007). Surveying instructor and learner attitudes toward e-learning. Computers and Education, 49, 1066-1080. http://dx.doi.org/10.1016/j.compedu.2006.01.001

Lin, C. H., \& Yu, S. F. (2008). Adolescent Internet usage in Taiwan: Exploring gender differences. Adolescence, 43, 317-331. http://www.ncbi.nlm.nih.gov/pubmed/18689104

Loyd, B. H., \& Gressard, C. (1984). The effects of sex, age, and computer experience on computer attitudes. AEDS Journal, 18, 67-77. http://dx.doi.org/10.1016/0747-5632(91)90020-2

Matthews, D., \& Shrum, L. (2003). High-speed Internet use and academic gratifications in the college residence. Internet and Higher Education, 6, 125-144. http://dx.doi.org/10.1016/S1096-7516(03)00020-4

Mcilroy, D., Sadler, C., \& Boojawon, N. (2007). Computer phobia and computer self-efficacy: Their association with undergraduates' use of university computer facilities, Computers in Human Behavior, 23, 1285-1299. http://dblp.uni-trier.de/db/journals/chb/chb23.html\#McilroySB07

Meelissen, M., \& Drent, M. (2008). Gender differences in computer attitudes: Does the school matter? Computers in Human Behavior, 24, 969-985. http://dx.doi.org/10.1016/j.chb.2007.03.001

Mitra, A. (1997). Toward evaluating computer aided instruction: Attitudes, demographics, content. Evaluation and Program Planning, 20, 379-391. http://dx.doi.org/10.1016/S0149-7189(97)00019-0

Moore, B. (1993). Predictors of high school students' attitudes towards involvement with mathematics. Mathematics Teacher, 42, 86-90.

Moras, S. (2001). Computer-Assisted Language Learning (CALL) And The Internet. Karen's Linguistic Issues. [Online] Available: http://www3.telus.net/linguisticsissues/ CALL.html (January 2003)

Opp-Beckman, L. (2002). Africa online: A web and content-based English language teaching course. TESOL Journal, 11, 4-8. [Online] Available: http://www.eric.ed.gov/ERICWebPortal/recordDetail?accno=EJ657495

Osman, M., \& Ahmed, H. (2003, October). Web assisted instruction: Its potentials and impact on students learning and attitudes. Paper presented at the conference of the Centre for Educational Technology (ETEX2003), Sultan Qaboos University, Sultanate of Oman.

Poynton, T. A. (2005). Computer literacy across the lifespan: A review with implications for educators. Computers in Human Behavior, 21, 861-872. http://dx.doi.org/10.1016/j.chb.2004.03.004

Selwyn, N. (1998). The effect of using a home computer on students' educational use of IT. Computers \& Education, 31, 211-227. http://dx.doi.org/10.1016/S0360-1315(98)00033-5

Tsou, W., Wang, W., \& Li, H. (2002). How computers facilitate English foreign language learners acquire English abstract words. Computers \& Education, 39, 415-428. http://dx.doi.org/10.1016/S0360-1315(02)00078-7

Vandewaeterea, M., \& Desmet, P. (2009). Introducing psychometrical validation of questionnaires in CALL research: The case of measuring attitude towards CALL. Computer Assisted Language Learning, 22, 349-380. http://dx.doi.org/10.1080/09588220903186547

Warschauer, M., \& Healey, D. (1998). Computers and language learning: An overview. Language Teaching, 31, 57-71. http://gse.uci.edu/person/warschauer_m/overview.html

Warschauer, M., Knoebel, M., \& Stone, L. (2004). Technology and equity in schooling: Deconstructing the digital divide. Educational Policy, 18, 562-588. http://dx.doi.org/10.1177/0895904804266469

Wong, S. L., Sidek Abdul Aziz, Aida Suraya Mohd Yunus, Zakaria Sidel, Kamariah Abu Bakar, \& Hamidah Meseran. (2005). Gender differences in information and communication technology competencies: A preliminary study among academicians at Universiti Putra Malaysia. Inovasi Teknologi Instruksional dalam Pengajaran dan Pembelajaran: Konvensyen Teknologi Pendidikan ke-18 (pp. 61-65). Terengganu: Persatuan Teknologi Pendidikan 
Malaysia.

[Online]

Available:

http://pppjj.usm.my/mojit/articles/pdf/Dec05/08\%20-\%20Gender_differences\%5B1\%5D-final.pdf

Young, S. S. C. (2003). Integrating ICT into second language education in a vocational high school. Journal of Computer Assisted Learning. 19, 447-461. [Online] http://faculty.ksu.edu.sa/Alhassan/2503/integrating\%20ICT\%202003.pdf

Available:

Table 1. Distribution of mean scores on A-CALL and its subparts $(n=142)$

\begin{tabular}{|c|c|c|}
\hline Scale & Mean & SD \\
\hline Factor 1 & 4.12 & 1.25 \\
\hline Factor 2 & 4.72 & 0.89 \\
\hline Factor 3 & 5.30 & 1.31 \\
\hline Factor 4 & 4.98 & 1.54 \\
\hline A-CALL & 4.74 & 0.76 \\
\hline
\end{tabular}

Table 2. Tests of Between-Subjects Effects for level of education and A-CALL subparts

\begin{tabular}{|l|c|c|c|c|c|c|}
\hline \multirow{3}{*}{ Source } & Dependent Variable & $\begin{array}{c}\text { Sum of } \\
\text { Squares }\end{array}$ & Mean Square & F & p & $\begin{array}{c}\text { Partial Eta } \\
\text { Squared }\end{array}$ \\
\hline Educational level & Factor 1 & 3.449 & 1.724 & 1.251 & .290 & .020 \\
\cline { 2 - 7 } & Factor 2 & 4.502 & 2.251 & 2.768 & .067 & .043 \\
\cline { 2 - 7 } & Factor 3 & 2.254 & 1.127 & .649 & .525 & .010 \\
\cline { 2 - 7 } & Factor 4 & 23.313 & 11.656 & 5.280 & $.006^{*}$ & .078 \\
\hline
\end{tabular}

Table 3. Descriptive statistics for A-CALL subparts by level of education

\begin{tabular}{|l|c|c|c|c|c|c|c|c|}
\hline \multirow{2}{*}{ Level of education } & \multicolumn{2}{|c|}{ Factor 1 } & \multicolumn{2}{c|}{ Factor 2 } & \multicolumn{2}{c|}{ Factor 3 } & \multicolumn{2}{c|}{ Factor 4 } \\
\cline { 2 - 9 } & Mean & SD & Mean & SD & Mean & SD & Mean & SD \\
\hline Junior high-school $(\mathrm{n}=50)$ & 4.040 & 1.401 & 4.850 & 1.017 & 5.533 & 1.321 & 4.693 & .702 \\
\hline High-school $(\mathrm{n}=49)$ & 4.107 & 1.188 & 4.714 & .803 & 5.238 & 1.278 & 5.108 & 1.559 \\
\hline University $(\mathrm{n}=43)$ & 4.482 & 1.122 & 4.581 & .856 & 5.100 & 1.344 & 5.170 & 1.283 \\
\hline Total $(\mathrm{n}=142)$ & 4.197 & 1.255 & 4.721 & .899 & 5.300 & 1.316 & 4.981 & 1.540 \\
\hline
\end{tabular}

Table 4. Tests of Between-Subjects Effects for A-CALL subparts and computer ownership

\begin{tabular}{|l|l|c|c|c|c|c|}
\hline \multirow{2}{*}{ Source } & \multicolumn{1}{|c|}{$\begin{array}{c}\text { Dependent } \\
\text { Variable }\end{array}$} & $\begin{array}{c}\text { Sum of } \\
\text { Squares }\end{array}$ & Mean Square & $\mathrm{F}$ & $\mathrm{p}$ & $\begin{array}{c}\text { Partial Eta } \\
\text { Squared }\end{array}$ \\
\hline Computer ownership & Factor 1 & 1.032 & 1.032 & .749 & .389 & .006 \\
\cline { 2 - 7 } & Factor 2 & .841 & .841 & 1.034 & .311 & .008 \\
\cline { 2 - 7 } & Factor 3 & 6.872 & 6.872 & 3.954 & $.049 *$ & .031 \\
\cline { 2 - 8 } & Factor 4 & 1.722 & 1.722 & .780 & .379 & .006 \\
\hline
\end{tabular}

Table 5. Descriptive statistics for A-CALL subparts and computer ownership

\begin{tabular}{|l|c|c|c|c|c|c|c|c|}
\hline \multirow{2}{*}{ Computer ownership } & \multicolumn{2}{c|}{ Factor 1 } & \multicolumn{2}{c|}{ Factor 2 } & \multicolumn{2}{c|}{ Factor 3 } & \multicolumn{2}{c|}{ Factor 4 } \\
\cline { 2 - 10 } & Mean & SD & Mean & SD & Mean & SD & Mean & SD \\
\hline No $(\mathrm{n}=62)$ & 4.092 & 1.131 & 4.674 & 1.003 & 5.236 & 1.423 & 5.021 & 1.606 \\
\hline Yes $(\mathrm{n}=80)$ & 4.313 & 1.315 & 4.759 & .8203 & 5.362 & 1.237 & 4.936 & 1.500 \\
\hline Total $(\mathrm{n}=142)$ & 4.216 & 1.238 & 4.722 & .903 & 5.307 & 1.319 & 4.974 & 1.543 \\
\hline
\end{tabular}

